\title{
Professor Ohannes Kafejian
}

\author{
Andréa Paula Kafejian Haddad'
}

'Disciplina de Cirurgia Vascular - Centro Universitário Saúde ABC (FMABC) - Santo André (SP), Brasil. E-mail: andrea.haddad@ fmabc.br

DOI: https://dx.doi.org/ 10.7322/abcshs.v44i3.1406

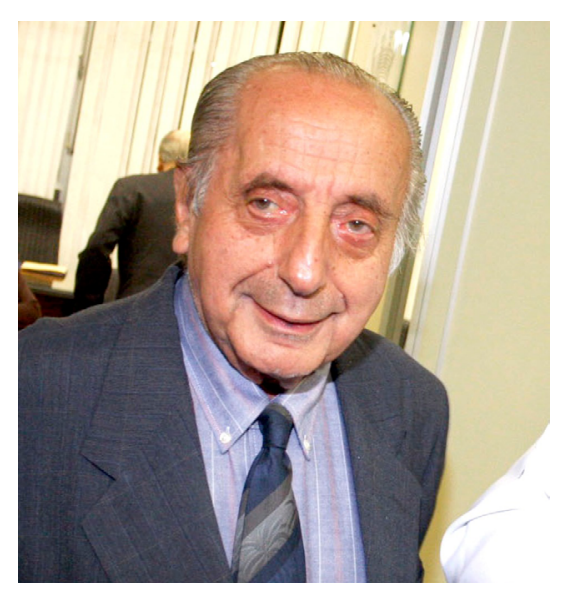

É com imenso carinho e gratidão que escrevo esta homenagem. Ohannes Kafejian nasceu em 21 de dezembro de 1930, descendente de imigrantes armênios, casou-se e teve três filhos (duas filhas e um filho).

Começou sua formação médica na Escola Paulista de Medicina, onde se formou em 1956. Ele contava que não imaginava ser cirurgião vascular, mas as circunstâncias o levaram a participar de um ambulatório de feridas no Instituto Nacional de Previdência Social (INPS) e então tudo começou.

A especialidade na época abriu oportunidades em sua vida, mas como ele dizia: "não existe sorte ou azar, mas sim oportunidades aos capacitados". Tornou- se, com a sua garra e determinação, um dos pioneiros da cirurgia arterial no Brasil! Viajava para Buenos Aires e lá no Hospital dos Ferroviários começou a aprender técnicas de revascularização, o que na época ninguém praticava em nosso meio. Não satisfeito, começou a viajar para Houston onde, com o cirurgião De Bakey, aprimorou seus conhecimentos. De volta ao Brasil aplicava as técnicas em seus pacientes e o sucesso no salvamento de membros e correção de aneurismas o deixava cada vez mais estimulado a aprender e a ensinar. Sempre defendeu que o conhecimento deveria ser repassado e não guardado para si, adorava ensinar.

Atuou no Hospital Santa Cruz onde operava e estabeleceu seu consultório. Foi chefe da Cirurgia Vascular no Hospital Heliópolis por 35 anos, onde pôde realizar e aprimorar suas técnicas operatórias, constituindo o serviço de residência em cirurgia vascular e formando uma série de especialistas, seus discípulos, distribuídos por todo o Brasil.

Realizava cursos ao vivo, inédito na época, com acompanhamento das cirurgias de revascularização dos membros, correção de aneurismas entre outras, onde ele mostrava o "pulo do gato", como dizia. No dia seguinte, os participantes do curso iam à enfermaria para constatar a boa evolução do procedimento. Ele contava isso com muito orgulho.

Quanto à carreira acadêmica, defendeu a tese de doutorado na Faculdade de Medicina de Taubaté, onde foi docente. Fez a livre docência e também lecionou na Escola Paulista de Medicina. Foi Professor Titular na Faculdade de Medicina do ABC, onde lecionou por 37 anos e recebeu o Título de Professor Emérito.

Participou da Sociedade de Angiologia e Cirurgia Vascular durante toda a sua trajetória, tornando-se sócio Emérito.

Sempre incentivou e atuou no ensino e na formação de grandes especialistas na nossa área.

O seu legado continua, suas mensagens e seu espírito de determinação permanecerão vivos em todos que puderam desfrutar de seu convívio, com felizes lembranças, ele dizia: "na vida você tem que ter um objetivo, não importa muito se você vai atingi-lo, mas se você tiver uma meta e se empenhar, provavelmente chegará lá“.

Esse foi meu pai, meu exemplo de vida, meu professor!

Muito obrigada! 